\title{
Toxic Impact of Exposure to Calcium Hypochlorite and Granular Activated Carbon on African Catfish (Clarias gariepinus): A Study of the Alterations in Hemato-Biochemical Profile and Oxidative Indices
}

\author{
Hager Tarek H Ismail
}

Department of Clinical Pathology, Faculty of Veterinary Medicine, Zagazig University, 1 Alzeraa Street, Zagazig, Sharkia, Province 44511, Egypt

*Corresponding author: hager_vet@hotmail.com; hagar_vet@zu.edu.eg

Article History: $21-334 \quad$ Received: 12 -Jun-21 1 Revised: 30 -Jun- 21 Accepted: 20 -Jul-21
A BS TRA C T
This study aimed to evaluate the hemato-biochemical parameters, oxidative stress indices and histopathological
alterations in different organs after exposure of fish to calcium hypochlorite $\left(\mathrm{Ca}(\mathrm{OCl})_{2}\right)$ as well as granular activated
carbon $(\mathrm{GAC})$ (unrinsed) as dechlorinator. A total of 96 Clarias gariepinus was divided equally into four groups in
triplicates: Group 1 was kept as a control, while groups 2,3 , and 4 were exposed (daily) to $\mathrm{Ca}(\mathrm{OCl})_{2}$ at a concentration
of $0.045 \mathrm{mg} / \mathrm{L}$ water, GAC at a concentration of $50 \mathrm{mg} / \mathrm{L}$ water and $\mathrm{Ca}(\mathrm{OCl})_{2}$ plus $\mathrm{GAC}$ at a same concentration of
previous groups, respectively. The exposures were conducted for $96 \mathrm{~h}$ after that blood and tissue samples were
collected for performing experimental tests. The results revealed that significant increase in erythrogram and
leukogram parameters, besides increase activities of serum alanine aminotransferase and aspartate aminotransferase
and concentrations of bilirubin fractions, total proteins, globulins, sodium, chloride, calcium, phosphorus and
ammonia in all experimental groups. Fourth group showed insignificant increase in red blood cells and monocytes
counts. Hyperalbuminemia was observed in Ca(OCl $)_{2}$ group alone. Serum alkaline phosphatase activity and creatinine
concentration were significantly decreased in all experimental groups. Malondialdehyde and hydrogen peroxide levels
showed significant increase, besides superoxide dismutases activity was decreased significantly in all experimental
groups in the liver, kidneys and gills tissues. In conclusion, chlorine caused hematological disturbances, hepato-renal
impairment with oxidative stress. Despite the importance of GAC as dechlorinator, it caused several adverse results
under the condition of this experiment, and this sheds light into the importance of safely use of GAC on aquatic
organisms.

Key words: Hematological, Biochemical, Oxidative indices, Calcium hypochlorite, Activated carbon.

\section{INTRODUCTION}

Clarias gariepinus is a principal clarid catfish in Africa and has been used largely as a laboratory fish model by many scientists to perform different scientific studies (Ibrahem 2012). Fish have a very close relationship with their surrounding environment, so poor water quality and waterborne toxicities most of the time kill-fish more than infectious agents (Roberts and Palmeiro 2008). So, it can be said that the ideal aquatic environment depends mainly on the water with high physicochemical quality (El-Sherbiny et al. 2019).

Elemental chlorine $\left(\mathrm{Cl}_{2}\right)$ and other chlorine compounds were used for many years in drinking water disinfection and wastewater treatment, where it plays an important role in prevention of waterborne infectious diseases spread, when used appropriately (Ghernaout 2017). Also, chlorination is one of the common and widely used practices in aquaculture for disinfecting fish hatcheries besides disinfection of fish production ponds by sterilization of tanks and standing water in drained ponds (Pons and Boyd 1998; Parker 2002). It is used in a liquid state as sodium hypochlorite $(\mathrm{NaOCl}$; bleach) or granular/powdered form as calcium hypochlorite $\left(\mathrm{Ca}(\mathrm{OCl})_{2}\right)$ for water sterilization (IPCS 2000). In case of aquacultural purposes, calcium hypochlorite is preferred to use in comparing with sodium hypochlorite. This is due to more available chlorine (about 65\%) in calcium hypochlorite, while the sodium hypochlorite has a low percentage of the active ingredient and less stable compound (Khan et al. 2008; Noga 2010; Hamdullah et al. 2010). In water, chlorine can be present as

Cite This Article as: Ismail HTH, 2022. Toxic impact of exposure to calcium hypochlorite and granular activated carbon on African catfish (Clarias gariepinus): a study of the alterations in hemato-biochemical profile and oxidative indices. International Journal of Veterinary Science 11(2): 129-140. https://doi.org/10.47278/journal.ijvs/2021.082 
hypochlorous acid and hypochlorite ions and is defined as "free available chlorine" or it may react with natural organic matter and form chlorinated disinfectant byproducts (DBPs), which fall under the combined chlorine category (IPCS 2000; Schmittinger 2000; Wu et al. 2021).

Despite the importance of chlorine as a disinfectant, the discharging of drinking water, heavily chlorinated wastewater and industrial chlorinated effluents into the aquatic system or addition of high concentrations of chlorine to fishponds for reducing bacterial population may leave high chlorine concentrations in aquatic environment (Cooke and Schreer 2001; Fisher et al. 2003). Chlorine can induce toxic effects to aquatic creatures such as gill damage which lead to respiratory difficulty, behavioral disturbances and some hematological abnormalities (Comfort et al. 2019). According to the most research reports, free chlorine is the most toxic form and therefore different dechlorination methods were established (Ganesh et al. 2006).

In the past years, more interest has been given to the potential use of activated carbon for dechlorination (Ganesh et al. 2006). Activated carbon (AC) is the common term for describing the family of carbonaceous adsorbents, commonly made from coal, wood, coconut shell and lignite and is available basically in three forms (granular, powder and pellet), which has been treated in a special way that makes their surfaces highly adsorbent with a massive surface area (Menéndez-Díaz and MartínGullónb 2006; Aly et al. 2016). It is being used in aquaculture to remove impurities out of water and removing the halogens such as chlorine, ozone and bromine, besides removing metabolic by-products in recirculating systems (Aly et al. 2016). According to previous studies, granular activated carbon (GAC) was used for chlorite removal by adsorption and chemical reduction, where the chemical reduction process on the surface of GAC becomes the main removal mechanism when the adsorptive sites are occupied (Collivignarelli et al. 2006).

Although several studies have reviewed chlorine toxicity of fresh and marine water fish which represented in studying different generalized physiological and behavioural responses for fish and most of the data in literature were in the 1970s, 1980s, and 1990s, but the pathological changes of chlorine toxicity are discussed rather briefly in previous literature (Cooke and Schreer 2001; Mahjoor and Loh 2008; Batley and Simpson 2020).

Furthermore, there are a lot of studies focusing on the positive effects of AC on pollutant removal in addition to both of its physical properties and the filtering effectiveness (Millward et al. 2005). On the other hand, the available information on possible deleterious effects of $\mathrm{AC}$ on the different biological parameters of aquatic species besides ecotoxicological effects are so limited and confined to aquatic invertebrates and other benthic organisms in sediments (Jonker et al. 2009). Limited studies have been performed on fish which suggested that GAC might be capable of causing head and lateral line erosion and the carbon dust (known as fines) was thought to be the causative agent for that. Exposure of fish to the carbon dust problem may happen for several reasons such as using low quality carbon (soft and dusty) or accidental occurrence of carbon crumbling and ejection into aquariums or use dry carbon, which unrinsed or soaked in distilled water before applying to the aquarium (Hemdal 2010; Hemdal and Odum 2011).

This study aimed to evaluate the hemato-biochemical parameters besides oxidative stress indices and histopathological alterations in the different organs to determine the possible pathological changes after exposure of fish to calcium hypochlorite as well as granular activated carbon (unrinsed) as a dechlorinator.

\section{MATERIALS AND METHODS}

\section{Tested Agents}

Calcium hypochlorite $\left(\mathrm{Ca}(\mathrm{OCl})_{2}\right)$ (technical grade) was used in granular form with $(65 \%)$ available chlorine, which is a product of (Sree Rayalaseema HI-Strength Hypo Limited, Andhra Pradesh, India). Granular activated carbon (GAC) was bought under the commercial name (NORIT GAC 830 PLUS), which is a product of Cabot Corporation USA and was purchased from the Egyptian distributor (Redachem Egypt Ltd.). It has a very high purity level with an iodine number 975 and a total surface area $1075 \mathrm{~m}^{2} / \mathrm{g}$.

\section{Fish}

A total of 96 apparently healthy Nile catfish (Clarias gariepinus) with a body weight $(200 \pm 10 \mathrm{~g})$ were used in this study. The fish were obtained and transported from the ponds of the Central Laboratory of Aquaculture Research, Abbassa, Abou-Hammad, Sharkia, Egypt to the fish unit in the Faculty of Veterinary Medicine, Zagazig University, Egypt. Fish were acclimatized for two weeks in stock ponds then randomly divided and maintained in 120 -litre rectangular glass aquaria $(100 \times 40 \times 30 \mathrm{~cm})$ of dechlorinated tap water. Continuous aeration was provided for each aquarium. Fish were fed during the experiment on a basal diet, which formulated to provide the proper nutrient needs of $C$. gariepinus in accordance with NRC (2011) recommendations. During the course of the experiment, the mean values of water quality indicators were temperature $28 \pm 2{ }^{\circ} \mathrm{C}, \mathrm{pH} \quad 7 \pm 0.5$ and dissolved oxygen $5-6 \mathrm{mg} / \mathrm{L}$ water. The photoperiod was 14h light: 10h darkness.

\section{Ethical Approval}

The study was approved by Zagazig University Institutional Animal Care and Use Committee "ZUIACUC”, Egypt (Approval No: ZUIACUC/2/F/141/2019).

\section{Experimental Design}

Fish were divided equally into four groups in a random manner (three replicates for each group, 8 fish/replicate). Group 1 was kept as a control without any exposure, group 2 was exposed to $\mathrm{Ca}(\mathrm{OCl})_{2}$ daily at a concentration of $0.045 \mathrm{mg} / \mathrm{L}$ water (Kolawole and Olukunle 2014) for $96 \mathrm{~h}$ period according to Halder et al. (2014). The exposure concentration of $\mathrm{Ca}(\mathrm{OCl})_{2}$ was selected in order to be representative of environmental concentrations encountered in the polluted water, where concentrations ranging from $0.04-0.2 \mathrm{mg} / \mathrm{L}$ were considered to be toxic to most of fish species according to Batley et al. (2021). Group 3 was exposed to GAC daily 
which was used directly as received without soaking or rinsing in distilled water and was applied into aquaria in a plastic mesh at a concentration of $50 \mathrm{mg} / \mathrm{L}$ water for $96 \mathrm{~h}$ period according to Hatt et al. (2013) and group 4 was exposed to $\mathrm{Ca}(\mathrm{OCl})_{2}$ plus $\mathrm{GAC}$ daily at a same concentration and duration of previous groups. Water in aquaria was replenished at $80 \%$ each $24 \mathrm{~h}$ to maintain constant exposure to tested agents and to remove unconsumed food and fecal matter by siphoning (staticrenewal exposure regime). Also, the clinical signs and mortality of fish were observed during the experimental period.

\section{Sampling}

Blood and tissue samples were collected at random from the fish in the different experimental groups after $96 \mathrm{~h}$ from starting the experiment. The fish were anaesthetized before sampling by using of clove oil at a concentration of $50 \mathrm{mg} / \mathrm{L}$ water through immersion in a separate container (Javahery et al. 2012). Blood samples were collected from a fish caudal vein (6/group) by using sterile disposable plastic syringe. The first part of collected blood, dispensed into sterilized tubes containing dipotassium salt of ethylene diamine tetra acetic acid (EDTA) for performing the different hematological tests. The second part of collected blood was dispensed into sterilized plain tubes, and then the serum was separated from clotted blood, which was centrifuged at 3000rpm for $15 \mathrm{~min}$ for performing the different biochemical analysis. Ten fish from each group were euthanized by decapitation and immediately the abdominal cavity of fish was opened for organs collection for oxidative stress indices estimation and histopathological evaluation.

\section{Hematological Studies}

Red blood cells (RBCs) and total leukocytes counts, hemoglobin $(\mathrm{Hb})$ concentration and hematocrit $(\mathrm{Ht})$ value were determined using an automated blood cell analyzer (Sysmex XT-2000iV, Kobe, Japan) (Harvey 2012). Giemsa-stained blood films were prepared for estimation of differential leukocytic count (Campbell 2015).

\section{Biochemical Studies}

The separated serum was analysed to determine the activities of alanine aminotransferase (ALT), aspartate aminotransferase (AST) and alkaline phosphatase (ALP) and concentrations of bilirubin (total and direct), total proteins, albumin, creatinine according to the methods described by Burtis and Ashwood (1999) and ammonia concentration according to the method stated by Neely and Phillipson (1988) and these parameters were determined using semi-auto chemistry analyzer (Chem-7 manufactured by Erba Diagnostics, Germany). Also, serum was used for the measurement of sodium $(\mathrm{Na})$ level according to Henry et al. (1974) and chloride $(\mathrm{Cl})$, calcium $(\mathrm{Ca})$ and phosphorus $(\mathrm{P})$ levels according to the methods described by Burtis and Ashwood (1999) and these parameters were measured using (ADVIA 1800 chemistry system manufactured by Siemens, Japan). Globulins concentration was obtained mathematically by take away the value of albumin from total proteins, and also indirect bilirubin was obtained by calculation via subtracting direct bilirubin from total bilirubin. All of these parameters were measured in kinetic or colorimetric way by using specific commercial kits (Spinreact, Spain).

\section{Oxidative Stress Indices in Tissues Homogenates}

Pieces $(0.25 \mathrm{~g})$ of the liver, kidneys and gills were weighed separately and rinsed with ice-cold saline to take off any blood clots then were grounded with cold phosphate buffered saline (PBS) solution ( $\mathrm{pH}$ 7.4). Finally, the prepared homogenates from the different organs were centrifuged and the collected supernatants were aliquoted for the oxidative stress indices estimation. Malondialdehyde (MDA) level in the various tissue homogenates was determined spectrophotometrically by using the method described by Ohkawa et al. (1979) by using a commercial kit (Biodiagnostics, Egypt). Tissue hydrogen peroxide $\left(\mathrm{H}_{2} \mathrm{O}_{2}\right)$ level was measured according to Halliwell and Gutteridge (1989) by using a colorimetric kit (Oxis International, Portland, OR, USA). Tissue superoxide dismutases (SOD) activity was estimated calorimetrically according to the method of Nishikimi et al. (1972) by using the kit (Biodiagnostics, Egypt). All these parameters were measured by using of photometer 5010 (Robert Riele GmbH and co-kg, Germany).

\section{Histopathological Study}

The selected organs for histopathological examination (liver, kidneys and gills) were collected, then fixed in $(10 \%)$ buffered neutral formalin solution, following by process of dehydration in a graded ethanol (70 to $100 \%)$, after that cleared in xylene and embedded in paraffin. Paraffin sections ( $5 \mu \mathrm{m}$ thick) were prepared, and finally stained with hematoxylin and eosin dyes, and then examined microscopically according to Suvarna et al. (2013).

\section{Statistical Analysis}

Data were analyzed by using SPSS statistical analysis package (version 21.0). One-way analysis of variance (ANOVA) was significant at $\mathrm{P}<0.05$ (Snedecor and Cochran, 1994) and Tukey's HSD post-hoc descriptive was used to test the significance differences between the mean values. All data in study are presented in the form of mean \pm SE.

\section{RESULTS}

\section{Clinical Observations and Survival}

Both of fish groups which were exposed to $\mathrm{Ca}(\mathrm{OCl})_{2}$ and GAC alone exhibited the signs of loss of reflexes, sluggish movement and restlessness besides covering of fish body and gills with a layer of mucus. While, the fish group exposed to $\mathrm{Ca}(\mathrm{OCl})_{2}$ plus GAC showed signs of restlessness, loss of movement coordination, air gulping and peeling of skin with excessive amount of mucus on body surface and gills. No mortality was observed in the control group, while fish exposed to $\mathrm{Ca}(\mathrm{OCl})_{2}$ alone recorded 3 mortalities, the group exposed to GAC alone recorded 4 mortalities and the group exposed to $\mathrm{Ca}(\mathrm{OCl})_{2}$ plus GAC recorded 5 mortalities. 


\section{Effects on Hematological Markers}

The hematological markers are presented in Table 1. Comparing with the control group, RBCs count showed significant increase in both groups exposed to $\mathrm{Ca}(\mathrm{OCl})_{2}$ and GAC alone, the highest value was observed in GACexposed group. While, the group exposed to $\mathrm{Ca}(\mathrm{OCl})_{2}$ plus GAC showed insignificant increase in comparison with control group. Also, the significant increase in $\mathrm{Hb}$ concentration and $\mathrm{Ht}$ value was observed in all experimental groups compared to the control, while the more pronounced change in $\mathrm{Hb}$ concentration was observed in the group exposed to GAC alone followed by group exposed to $\mathrm{Ca}(\mathrm{OCl})_{2}$ alone then $\mathrm{Ca}(\mathrm{OCl})_{2}$ plus GAC group. With regard to $\mathrm{Ht}$ value, the highest value was detected in the group exposed to GAC alone.

Total leukocytes, heterophils and lymphocytes counts were significantly increased in all experimental groups compared to the control group, the highest values of these parameters were observed in the group exposed to GAC alone followed by group exposed to $\mathrm{Ca}(\mathrm{OCl})_{2}$ alone, while group exposed to $\mathrm{Ca}(\mathrm{OCl})_{2}$ plus $\mathrm{GAC}$ showed the lowest values. Compared with the control group, monocytes count showed significant increase in both of groups exposed to $\mathrm{Ca}(\mathrm{OCl})_{2}$ and $\mathrm{GAC}$ alone and insignificant increase in the group exposed to $\mathrm{Ca}(\mathrm{OCl})_{2}$ plus GAC.On the other hand, the eosinophils and basophils showed non-significant statistical change in all experimental groups.

\section{Effects on Biochemical Markers}

Table 2 illustrates a significant increase in the serum ALT and AST activities, bilirubin (total, direct, and indirect), total proteins, globulins, sodium, chloride, calcium, phosphorus, and ammonia concentrations in all experimental groups in comparison with the control group. The highest values of serum ALT and AST activities and bilirubin (total, direct, and indirect), sodium, chloride and ammonia concentrations were observed in the fish group exposed to both of $\mathrm{Ca}(\mathrm{OCl})_{2}$ and $\mathrm{GAC}$ followed by the fish group exposed to GAC alone and finally the group exposed to $\mathrm{Ca}(\mathrm{OCl})_{2}$ alone. On the other hand, the highest value of serum total proteins concentration was observed in the group exposed to $\mathrm{Ca}(\mathrm{OCl})_{2}$ alone followed by the group exposed to $\mathrm{Ca}(\mathrm{OCl})_{2}$ plus $\mathrm{GAC}$, while the fish in the GAC group displayed the lowest value in this parameter, besides that serum globulins concentration appeared more pronounced in both groups exposed to $\mathrm{Ca}(\mathrm{OCl})_{2}$ alone and $\mathrm{Ca}(\mathrm{OCl})_{2}$ plus GAC. Serum calcium concentration was more obvious in group exposed to $\mathrm{Ca}(\mathrm{OCl})_{2}$ plus GAC. While, serum phosphorus concentration was more pronounced in the group exposed to GAC alone. Serum albumin concentration showed a significant increase in the group exposed to $\mathrm{Ca}(\mathrm{OCl})_{2}$ alone and non-significant change in other groups in comparison with the control group. Compared with the control group, serum ALP activity and creatinine concentration showed a significant decrease in all experimental groups. The lowest value of serum ALP activity was observed in the group exposed to $\mathrm{Ca}(\mathrm{OCl})_{2}$ alone.

\section{Effects on Oxidative Stress Indices}

Regarding the results of MDA and $\mathrm{H}_{2} \mathrm{O}_{2}$ levels in the liver, kidneys and gills tissues, significant increase was found in all experimental groups relative to the control group in all tested tissues (Figs. 1 and 2). The highest values in all tested tissues were detected in the group exposed to $\mathrm{Ca}(\mathrm{OCl})_{2}$ plus GAC. Conversely, SOD activity was decreased significantly in all experimental groups compared with the control group in the liver, kidneys and gills tissues (Fig. 3). The lowest values in all tested tissues were observed in the group exposed to $\mathrm{Ca}(\mathrm{OCl})_{2}$ plus $\mathrm{GAC}$.
A

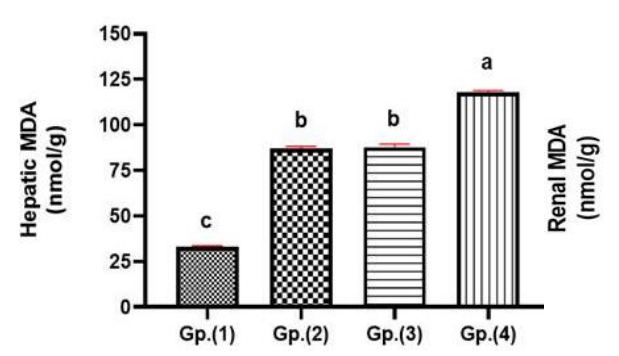

B

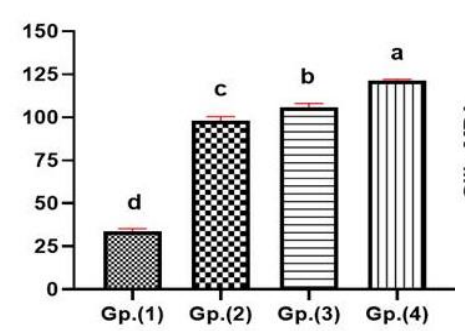

C

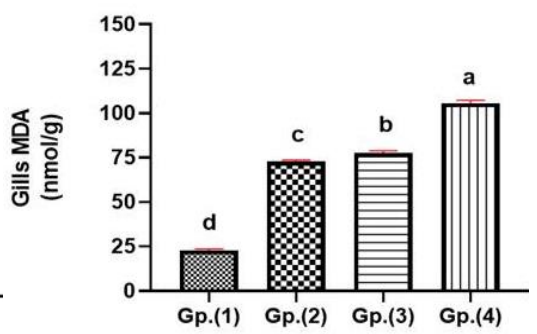

Fig. I: MDA level in the liver, kidneys and gills in the different fish groups after $96 \mathrm{~h}$ from starting the experiment. Data are expressed in the form of mean \pm SE. Bars with different letters are significantly different $(P<0.05)$ and the highest value was represented by the letter $(a)$; same letters indicate no differences. Gp. (I) Control group, Gp. (2) $\mathrm{Ca}(\mathrm{OCl})_{2}$ group, Gp. (3) GAC group, Gp. (4) $\mathrm{Ca}(\mathrm{OCl})_{2}$ plus $\mathrm{GAC}$ group.

Table I: Some hematological markers in groups (I-4) after $96 \mathrm{~h}$ from starting the experiment

\begin{tabular}{|c|c|c|c|c|c|}
\hline \multirow[t]{2}{*}{ Analytes } & \multirow[b]{2}{*}{ Gp. (I) } & \multicolumn{3}{|c|}{ Experimental groups } & \multirow[t]{2}{*}{ P Value } \\
\hline & & Gp. (2) & Gp. (3) & Gp. (4) & \\
\hline RBCs $\left(\times 10^{6} / \mu \mathrm{l}\right)$ & $2.55 \pm 0.025 c$ & $3.17 \pm 0.049 b$ & $4.44 \pm 0.280 a$ & $3.00 \pm 0.032 b c$ & $<0.001$ \\
\hline $\mathrm{Hb}(\mathrm{g} \%)$ & $8.98 \pm 0.064 d$ & $11.92 \pm 0.036 b$ & $12.60 \pm 0.29 \mid \mathrm{a}$ & $10.90 \pm 0.118 c$ & $<0.001$ \\
\hline $\mathrm{Ht}(\%)$ & $27.57 \pm 0.117 c$ & $33.24 \pm 0.506 b$ & $38.00 \pm 0.707 a$ & $32.00 \pm 0.547 b$ & $<0.001$ \\
\hline $\operatorname{TLC}\left(\times 10^{3} / \mu \mathrm{l}\right)$ & $25.78 \pm 0.265 d$ & $48.02 \pm 0.654 b$ & $58.13 \pm 0.67 \mathrm{Ia}$ & $38.00 \pm 0.707 c$ & $<0.001$ \\
\hline Heterophils $\left(\times 10^{3} / \mu \mathrm{l}\right)$ & $\mathrm{II} .80 \pm 0.25 \mathrm{Id}$ & $19.02 \pm 0.317 b$ & $25.49 \pm 0.636 a$ & $16.49 \pm 0.492 c$ & $<0.001$ \\
\hline Lymphocytes $\left(\times 10^{3} / \mu \mathrm{l}\right)$ & $\mathrm{Il} .47 \pm 0.20 \mathrm{ld}$ & $24.84 \pm 0.382 b$ & $27.86 \pm 0.540 \mathrm{a}$ & $18.16 \pm 0.387 c$ & $<0.001$ \\
\hline Monocytes $\left(\times 10^{3} / \mu \mathrm{l}\right)$ & $2.11 \pm 0.126 c$ & $3.46 \pm 0.222 \mathrm{ab}$ & $4.20 \pm 0.262 \mathrm{a}$ & $2.89 \pm 0.13 \mathrm{Ibc}$ & $<0.001$ \\
\hline Eosinophils $\left(\times 10^{3} / \mu \mathrm{l}\right)$ & $0.25 \pm 0.079$ & $0.48 \pm 0.145$ & $0.43 \pm 0.113$ & $0.39 \pm 0.123$ & 0.595 \\
\hline Basophils $\left(\times 10^{3} / \mu \mathrm{l}\right)$ & $0.15 \pm 0.062$ & $0.22 \pm 0.108$ & $0.15 \pm 0.114$ & $0.07 \pm 0.078$ & 0.750 \\
\hline
\end{tabular}

Data were presented in the form of mean \pm SE. Means bearing different alphabets within the same row are significantly $(P<0.05)$ different. No letters indicate (P>0.05). Gp. (I) Control group, Gp. (2) $\mathrm{Ca}(\mathrm{OCl})_{2}$ group, Gp. (3) GAC group, Gp. (4) $\mathrm{Ca}(\mathrm{OCl})_{2} \mathrm{plus} \mathrm{GAC}$ group. RBCs, red blood cells; $\mathrm{Hb}$, hemoglobin; Ht, hematocrit; T.L.C., total leukocytic count. 
A

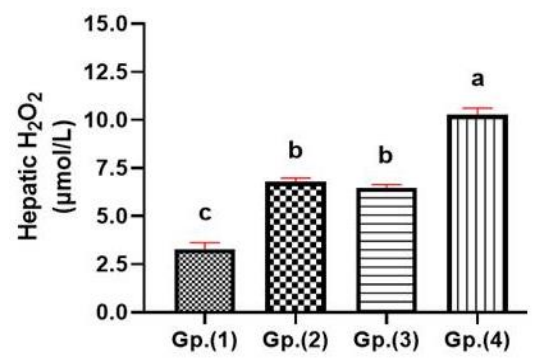

B

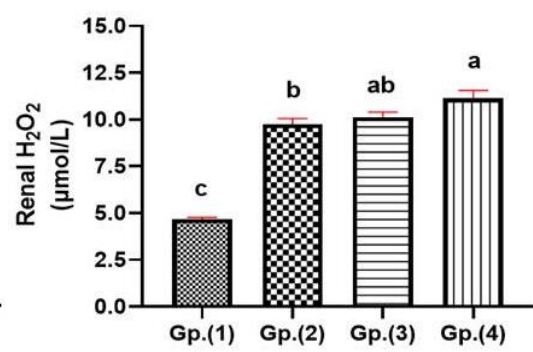

C

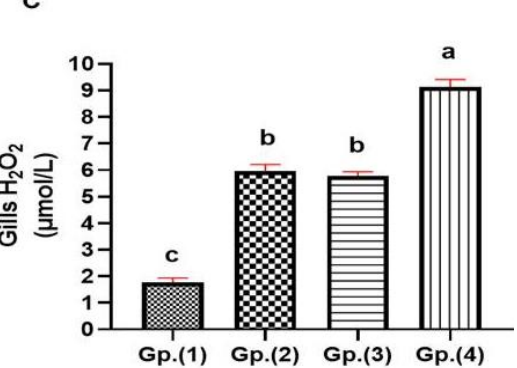

Fig. 2: $\mathrm{H}_{2} \mathrm{O}_{2}$ level in liver, kidneys and gills in the different fish groups after $96 \mathrm{~h}$ from starting the experiment. Data are expressed in the form of mean \pm SE. Bars with different letters are significantly different $(P<0.05)$ and the highest value was represented by the letter $(a)$; same letters indicate no differences. Gp. (I) Control group, Gp. (2) $\mathrm{Ca}(\mathrm{OCl})_{2}$ group, Gp.(3) $\mathrm{GAC}$ group, $\mathrm{Gp}$. (4) $\mathrm{Ca}(\mathrm{OCl})_{2}$ plus $\mathrm{GAC}$ group.

A

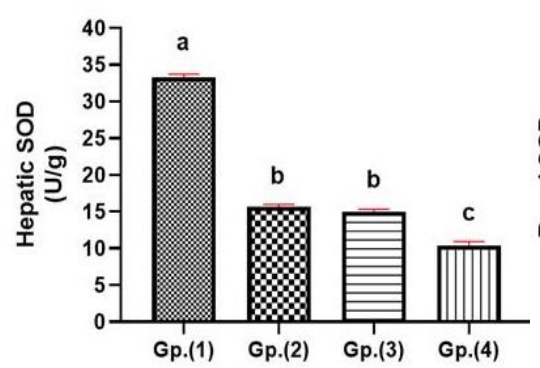

B

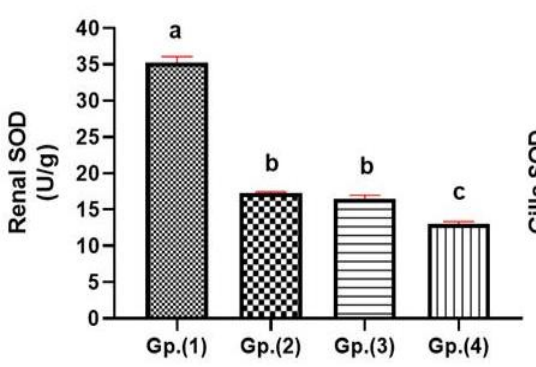

C

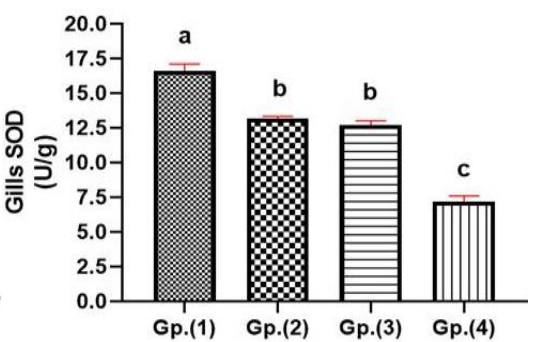

Fig. 3: SOD activity in liver, kidneys and gills in the different fish groups after $96 \mathrm{~h}$ from starting the experiment. Data are expressed in the form of mean \pm SE. Bars with different letters are significantly different $(p<0.05)$ and the highest value was represented by the letter $(a)$; same letters indicate no differences. Gp. (I) Control group, Gp. (2) $\mathrm{Ca}(\mathrm{OCl})_{2}$ group, Gp. (3) GAC group, Gp. (4) $\mathrm{Ca}(\mathrm{OCl})_{2}$ plus GAC group.

Table 2: Some serum biochemical markers of groups ( $1-4)$ after $96 \mathrm{~h}$ from starting the experiment

\begin{tabular}{|c|c|c|c|c|c|}
\hline \multirow[t]{2}{*}{ Analytes } & \multirow[b]{2}{*}{ Gp. (I) } & \multicolumn{3}{|c|}{ Experimental groups } & \multirow[t]{2}{*}{ P Value } \\
\hline & & Gp. (2) & Gp. (3) & Gp. (4) & \\
\hline ALT (U/L) & $|7.53 \pm 0.70| \mathrm{d}$ & $22.72 \pm 0.794 c$ & $27.77 \pm 0.73 \mathrm{Ib}$ & $73.76 \pm 1.185 a$ & $<0.001$ \\
\hline AST (U/L) & 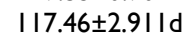 & $217.78 \pm 2.536 c$ & $274.36 \pm 2.75 \mathrm{lb}$ & $293.68 \pm 2.091 \mathrm{a}$ & $<0.001$ \\
\hline ALP (U/L) & $20.6 I \pm 0.903 a$ & $9.84 \pm 0.546 \mathrm{~d}$ & $|7.4| \pm 0.677 b$ & $13.60 \pm 0.325 c$ & $<0.001$ \\
\hline Total bilirubin (mg/dl) & $0.42 \pm 0.022 d$ & $0.62 \pm 0.016 c$ & $0.7 \mathrm{I} \pm 0.0 \mathrm{I} 3 \mathrm{~b}$ & $0.78 \pm 0.008 a$ & $<0.001$ \\
\hline Direct bilirubin (mg/dl) & $0.10 \pm 0.005 c$ & $0.13 \pm 0.006 b$ & $0.15 \pm 0.004 \mathrm{ab}$ & $0.17 \pm 0.005 a$ & $<0.001$ \\
\hline Indirect bilirubin (mg/dl) & $0.32 \pm 0.019 d$ & $0.49 \pm 0.010 c$ & $0.56 \pm 0.0 \mathrm{IIb}$ & $0.61 \pm 0.004 a$ & $<0.001$ \\
\hline Total proteins (g/dl) & $3.21 \pm 0.055 d$ & $5.12 \pm 0.066 a$ & $3.7 I \pm 0.044 c$ & $4.31 \pm 0.078 b$ & $<0.001$ \\
\hline Albumin $(\mathrm{g} / \mathrm{dl})$ & I. $19 \pm 0.044 b$ & $1.85 \pm 0.027 \mathrm{a}$ & I.24 $240.032 b$ & $1.29 \pm 0.035 b$ & $<0.001$ \\
\hline Globulins (g/dl) & $2.02 \pm 0.058 c$ & $3.27 \pm 0.073 a$ & $2.47 \pm 0.055 b$ & $3.02 \pm 0.075 a$ & $<0.001$ \\
\hline Creatinine (mg/dl) & $0.52 \pm 0.013 a$ & $0.43 \pm 0.010 \mathrm{~b}$ & $0.38 \pm 0.010 c$ & $0.36 \pm 0.012 c$ & $<0.001$ \\
\hline Sodium $(\mathrm{mmol} / \mathrm{l})$ & $123.06 \pm 0.864 d$ & $142.30 \pm 0.964 c$ & $155.40 \pm I .164 \mathrm{~b}$ & $179.79 \pm 2.500 \mathrm{a}$ & $<0.001$ \\
\hline Chloride $(\mathrm{mmol} / \mathrm{l})$ & $82.89 \pm 1.643 d$ & $93.22 \pm 1.52 \mathrm{Ic}$ & $\mathrm{I} 06.42 \pm \mathrm{I} .70 \mathrm{Ib}$ & $118.12 \pm 1.167 \mathrm{a}$ & $<0.001$ \\
\hline Calcium (mg/dl) & $8.79 \pm 0.174 c$ & $9.61 \pm 0.142 \mathrm{ab}$ & $9.46 \pm 0.124 b$ & $10.18 \pm 0.077 \mathrm{a}$ & $<0.001$ \\
\hline Phosphorus (mg/dl) & $9.82 \pm 0.182 c$ & $11.66 \pm 0.092 b$ & $12.87 \pm 0.190 \mathrm{a}$ & $\mid \mathrm{l} .68 \pm 0.213 \mathrm{~b}$ & $<0.001$ \\
\hline Ammonia (mg/dl) & $0.02 \pm 0.001 \mathrm{~d}$ & $0.04 \pm 0.00 \mathrm{lc}$ & $0.06 \pm 0.002 b$ & $0.07 \pm 0.00 \mathrm{la}$ & $<0.001$ \\
\hline
\end{tabular}

Data were presented in the form of mean \pm SE. Means bearing different alphabets within the same row are significantly $(\mathrm{P}<0.05)$ different. Gp. $(\mathrm{I})$ Control group, Gp. (2) $\mathrm{Ca}(\mathrm{OCl})_{2}$ group, Gp. (3) GAC group, Gp. (4) $\mathrm{Ca}(\mathrm{OCl})_{2}$ plus GAC group. ALT, alanine aminotransferase; AST, aspartate aminotransferase; ALP, alkaline phosphatase.

\section{Histopathological Findings}

Liver: The examined liver of fish in the control group showed normal lobular arrangement, central venules, hepatocytes, sinusoids and reticulio-endothelial system are well formed and histologically normal (Fig. 4a). Furthermore, the photomicrographs of liver regard to the group exposed to $\mathrm{Ca}(\mathrm{OCl})_{2}$ alone showed degenerative vasculitis with associated perivascular edema. Also, the hepato-portal area revealed remarkable edema and lymphocytic aggregations, peri-portal and interstitial aggregations of melano-macrophages and or lymphocytes are detected (Fig. 4b and 4c). On the other hand, the hepatopathological assessment of the fish group exposed to GAC alone revealed that moderate hepato-portal vascular congestion, perivascular edema beside hepatocytes apoptotic and degenerative changes in a moderate number of cells (Fig. 4d and 4e). The hepatic histological architecture of fish group, which exposed to both $\mathrm{Ca}(\mathrm{OCl})_{2}$ and $\mathrm{GAC}$ showed severe dilatation and erythrocytic-leukocytic cytosis of the hepato-portal veins with perivascular lymphocytic aggregation. Mild to moderate numbers of hepatocytes were degenerated and or apoptotic (Fig. 4f and 4g).

Kidneys: Histology of renal tissue of fish in the control group showed normal renal glomerular, tubular and interstitial structures with minimal round cells infiltrations in the latter (Fig. 5a). On the other hand, the renal photomicrographs of fish group exposed to $\mathrm{Ca}(\mathrm{OCl})_{2}$ alone showed severe congestion of the blood vessels, massive renal tubular atrophic, degenerative and necrotic changes, extensive interstitial lymphocytic infiltration, 

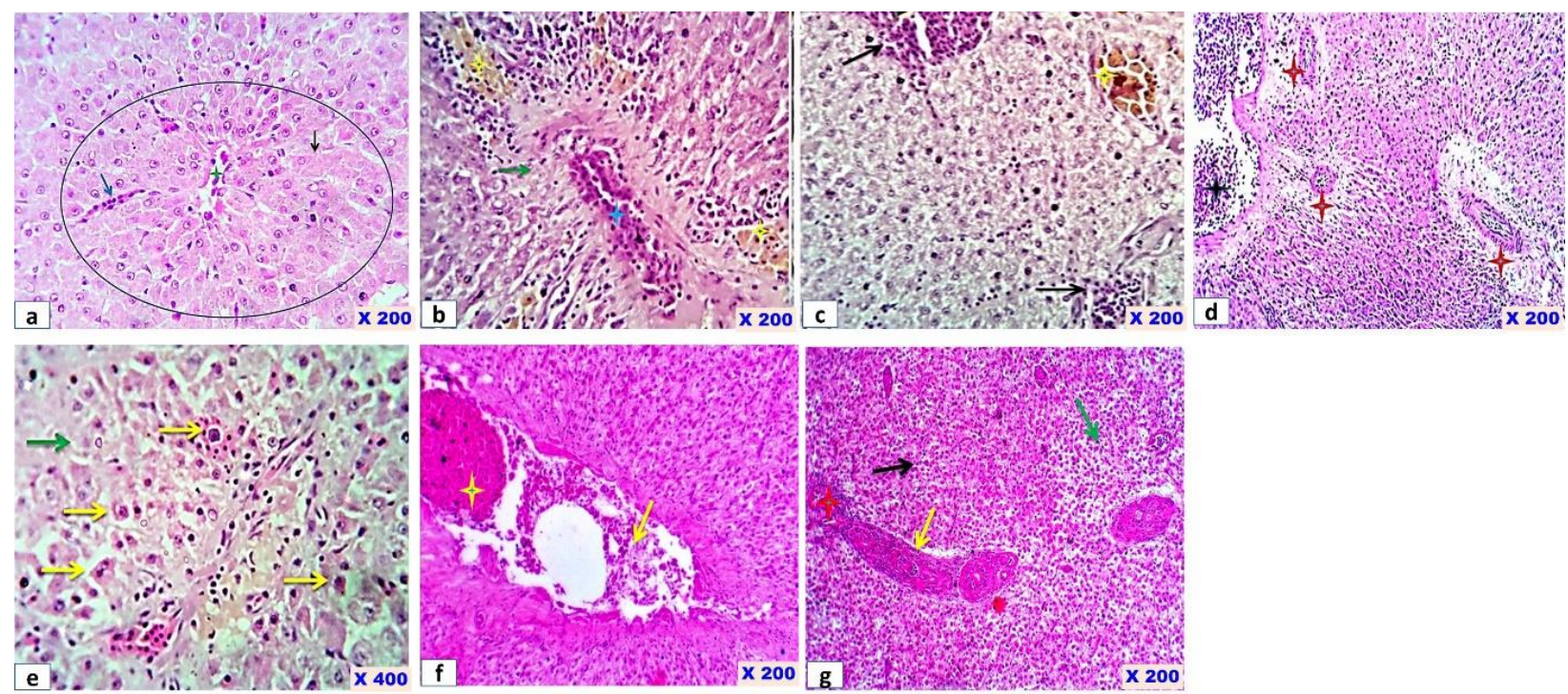

Fig. 4: Photomicrograph of H\&E-stained sections. (a) Liver section of control group showing normal lobular arrangement (circle), central venules (star), the hepatocytes (black arrow), sinusoids (blue arrow) and reticulio-endothelial system are well formed and histologically normal. Liver sections of group exposed to $\mathrm{Ca}(\mathrm{OCl})_{2}$ alone showing $(\mathrm{b}, \mathrm{c})$ degenerative vasculitis with associated perivascular edema (blue stars and green arrow), the hepato-portal area shows remarkable edema and lymphocytic aggregations (black arrows) and peri-portal and interstitial aggregations of melanomacrophages and or lymphocytes are seen (yellow stars). Liver sections of group exposed to GAC alone showing (d, e) moderate hepato-portal vascular congestion (black star), perivascular edema (red stars) beside hepatocytes apoptotic and degenerative changes in a moderate number of cells (yellow and green arrows). Liver sections of group exposed to $\mathrm{Ca}(\mathrm{OCl})_{2}$ plus $\mathrm{GAC}$ showing (f, g) severe dilatation and erythrocytic-leukocytic cytosis of the hepato-portal veins (yellow arrows and stars) with perivascular lymphocytic aggregation (red star) and mild to moderate numbers of hepatocytes were degenerated and/or apoptotic (green and black arrows).
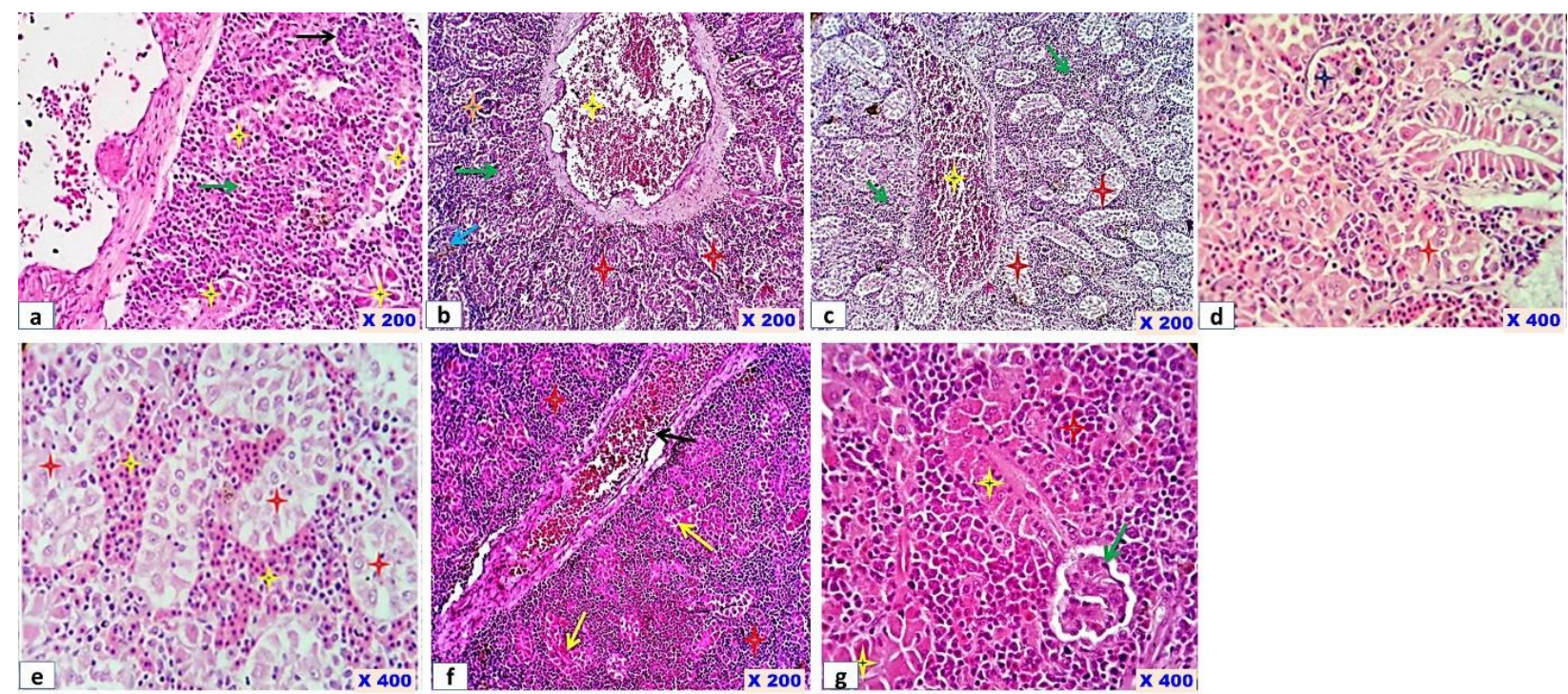

Fig. 5: Photomicrograph of H\&E-stained sections. (a) Kidney section of control group showing normal renal glomerular (black arrow), tubular (yellow stars) and interstitial structures with minimal round cells infiltrations in the latter (green arrows). Kidney sections of group exposed to $\mathrm{Ca}(\mathrm{OCl})_{2}$ alone showing $(\mathrm{b}, \mathrm{c})$ severe congestion of the blood vessels (yellow stars), massive renal tubular atrophic, degenerative and necrotic changes (red stars), extensive interstitial lymphocytic infiltration (green arrows), glomerular shrinking and or lobulation (orange star) and focal aggregations of melano-macrophages (blue arrow). Kidney sections of group exposed to GAC alone showing (d, e) massive renal-tubular degenerative and early necrotic and/or apoptotic changes (red stars), hyperemia of the blood vessels and extensive interstitial lympho-plasmacytic infiltration and aggregation (yellow stars), while the glomeruli showed unremarkable changes (dark blue star). Kidney sections of group exposed to $\mathrm{Ca}(\mathrm{OCl})_{2} \mathrm{Plus}$ GAC showing ( $f, g)$ tubular degenerative and early necrotic changes beside a few cells suffering apoptotic changes (yellow arrows and stars), the blood vessels were moderately congested (black arrow), the interstitium showed moderate aggregations of lympho-plasmacytes (red stars) and some glomeruli are atrophic (green arrow).

glomerular shrinking and/or lobulation and focal aggregations of melano-macrophages (Fig. 5b and 5c). Looking to the examined kidney sections of fish group exposed to GAC alone, massive renal-tubular degenerative and early necrotic or apoptotic changes were found. Also, hyperemia of the blood vessels and extensive interstitial lympho-plasmacytic infiltration and aggregation were observed. Focal renal tubular neoplastic change was seen in a few examined slides. The glomeruli showed unremarkable changes (Fig. 5d and 5e). In fish group exposed to both of $\mathrm{Ca}(\mathrm{OCl})_{2}$ and $\mathrm{GAC}$, renal photomicrographs showed tubular degenerative and early necrotic changes beside a few cells suffering apoptotic changes The blood vessels were moderately congested. The interstitium showed moderate aggregations of lymphoplasmacytes. Some glomeruli are atrophic (Fig. $5 \mathrm{f}$ and $5 \mathrm{~g}$ ). 


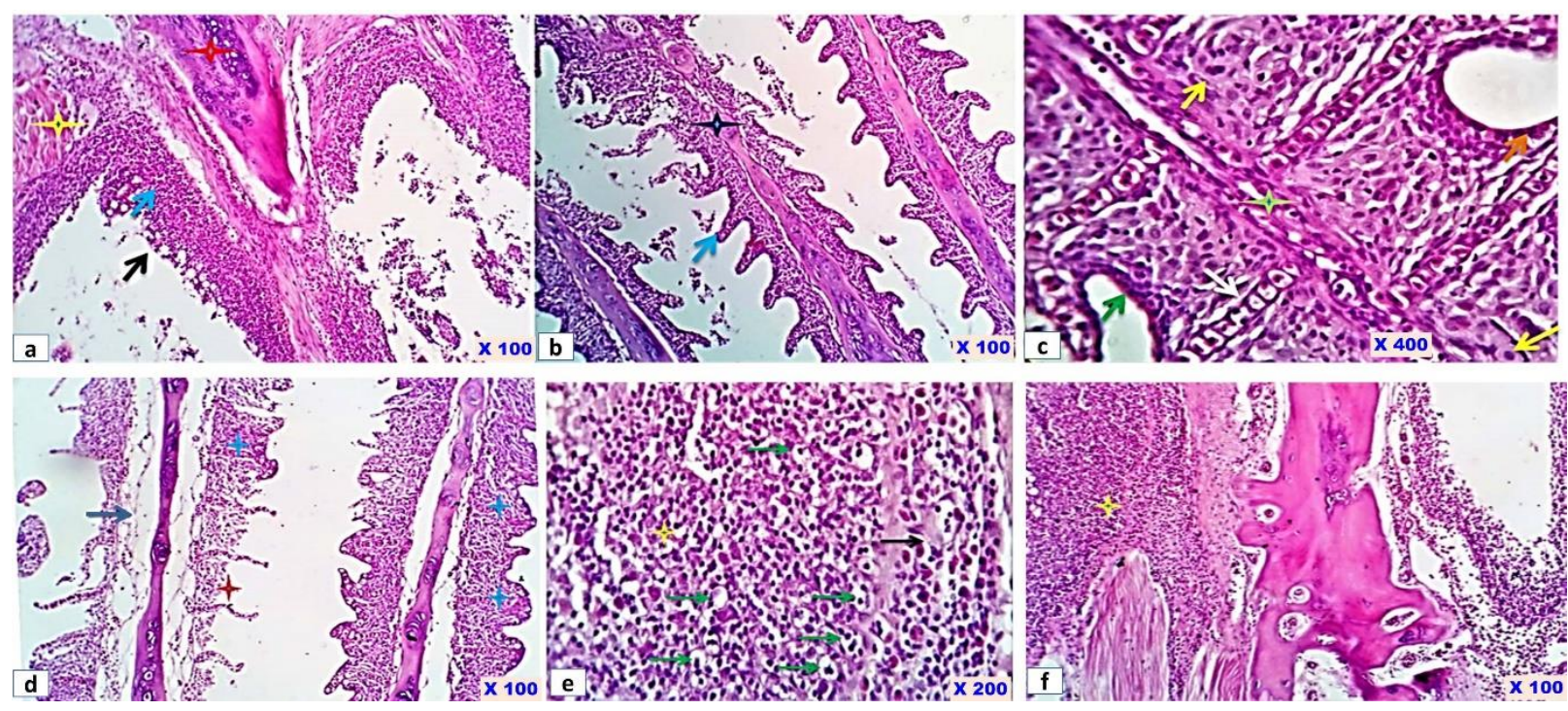

Fig. 6: Photomicrograph of H\&E-stained sections. Gills sections of control group showing the histomorphological structures of (a) gill arch (Fibromasculaar elements, yellow star), carteliigenous terminals (red star) and stromal cells (eosinophilic granular cells and round cells, black and blue arrows), (b) primary and secondary gill filament (blue arrow and star), (c) lamellar pavement cells (green arrow), epithelial cells (orang arrow), chloride cells (yellow arrow) and efferent venule (green star). Gills sections of group exposed to $\mathrm{Ca}(\mathrm{OCl})_{2}$ alone showing (d-f) focal epithelial lifting, denudation and necrosis (red star) or epithelial hyperplasia with subepithelial aggregations of eosinophilic granular cells, lymphocytes, and many chloride cells, mostly with clear vacuolated cytoplasm (blue stars and green arrows), besides congestion of the efferent gill venules, which are stuffed by lymphocytes (black arrow) and sometimes accompanied perivascular edematous changes (dark blue arrow). The gill arch showed large collections of lymphocytes, eosinophilic granular cells and macrophages (yellow star).

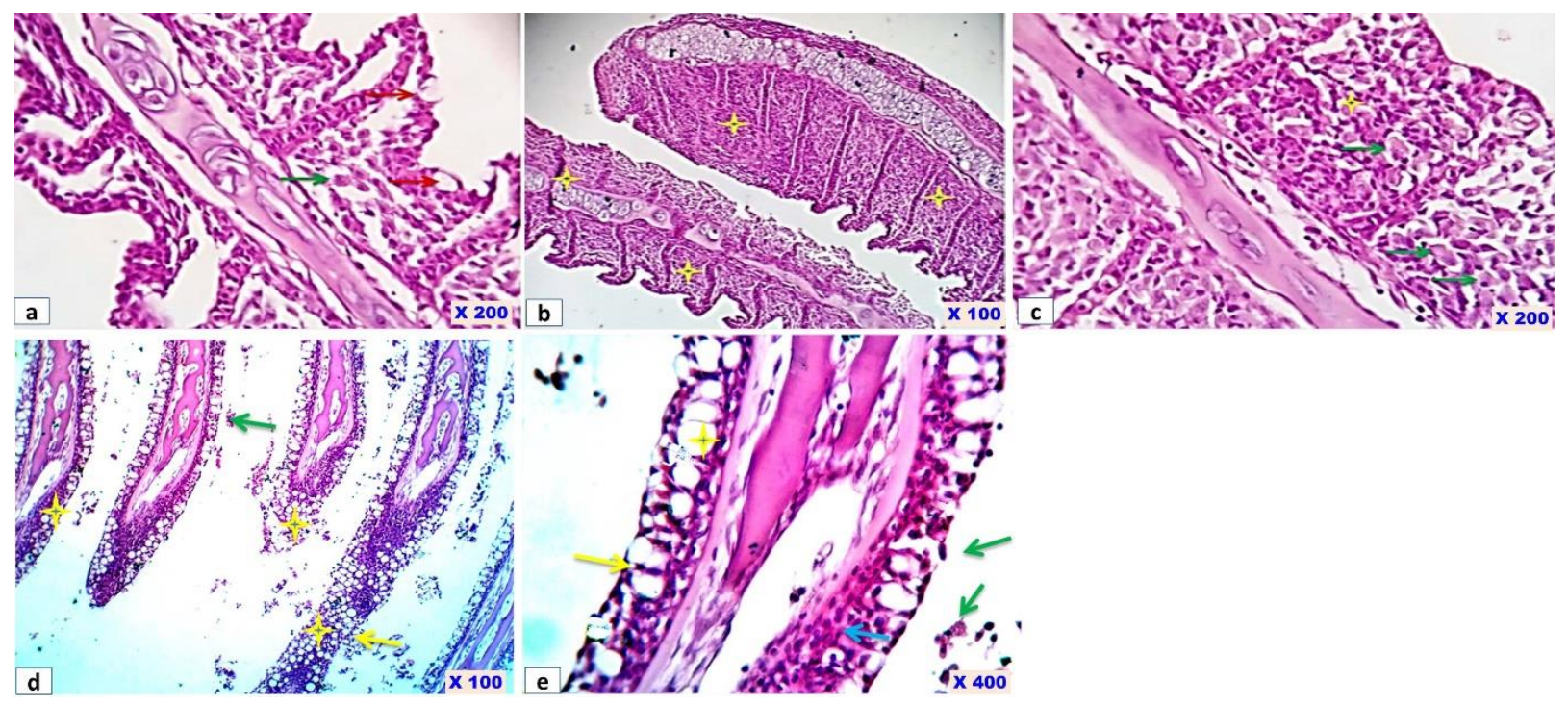

Fig. 7: Photomicrograph of H\&E-stained sections. Gills sections of group exposed to GAC alone showing (a-b) gill filaments either focally denuded from their epithelial lining with superficial vacuolations and subepithelial aggregation of macrophages and chloride cells (red and green arrows) or they are of proliferative nature (yellow stars) with (c) secondary gill filament adhesion due to chloride cell hyperplasia (green arrows) and lymphoplasmacytic infiltration and epithelial hypertrophy and hyperplasia. Gills sections of group exposed to $\mathrm{Ca}(\mathrm{OCl})_{2}$ plus $\mathrm{GAC}$ showing (d, e) extreme vacuolation of the filament epithelial lining (spongiosis) (yellow stars and arrows), epithelial lifting (green arrow), hyperemia of the efferent venules and mild lymphocytic infiltration (blue arrow).

Gills: Examined serial sections from the gills of control fish revealed normal histo-morphologic structures, including the gill rockers with its epithelial lining that comprise mucus cells, chloride cells and the subepithelial stromal cells (eosinophilic granular cells and some lymphocytes). The gill arch showed normal fibromascular elements, osteo-cartilagenous terminals and stromal structures comprising some mononuclear cells and eosinophilic granular cells. The primary and secondary gill filaments were apparently normal with normal pavement cells, lamellar epithelial cells, pillar cells, mucus secreting cells (goblet cells), chloride cells, capillary channels (afferent and efferent venules) and a few mononuclear cells (Fig. 6a-c). Examined gills sections of the group exposed to $\mathrm{Ca}(\mathrm{OCl})_{2}$ alone denoted remarkable changes particularly in the secondary filaments represented by focal controversial epithelial lifting, denudation and necrosis or epithelial hyperplasia with subepithelial aggregations of eosinophilic granular cells, lymphocytes, and many chloride cells, mostly with clear vacuolated cytoplasm. Congestion of the efferent gill venules, which were stuffed by lymphocytes sometimes, accompanied perivascular edematous changes were recorded. The gill arch showed large collections of 
lymphocytes, eosinophilic granular cells and macrophages (Fig. 6d-f). Highly sophisticated changes were noticed in the group exposed to GAC alone as the gill filaments were either focally denuded from their epithelial lining with superficial vacuolations and subepithelial aggregation of macrophages and chloride cells or they were of proliferative nature with secondary gill filament adhesion due to chloride cell hyperplasia and lympho-plasmacytic infiltration and epithelial hypertrophy and hyperplasia (Fig. 7a-c). Examined serial sections of gills in fish group exposed to $\mathrm{Ca}(\mathrm{OCl})_{2}$ and $\mathrm{GAC}$ revealed extreme vacuolation of the filament epithelial lining (spongiosis), epithelial lifting, hyperemia of the efferent venules and mild lymphocytic infiltration. The gill arch showed massive infiltration and aggregation of lymphoplasmacytes and eosinophilic granular cells (Fig. 7 d-e).

\section{DISCUSSION}

Despite the big and important role of chlorine as a disinfectant, sensitivity of fish to chlorine as well as its toxicity has been recorded by several studies (Heath 1997; Yonkos et al. 2000; Kowalska et al. 2006). For this reason, a number of methods have been developed for removing or reducing free chlorine residuals and activated carbon was the most common way between different dechlorination processes (Salama et al. 2016). Quality of water can be identified by the fish living in it, whereas fish health condition gives a good indication about the health situation of the aquatic ecosystem. Early toxic effects of chemicals or pollutants are visible on the level of cells or tissues, even before the appearance of specified or significant changes in fish external appearance or behavior (Aswale et al. 2019).

Measurement of hematological parameters can be used as indicators for critical changes following exposure to the environmental stressful conditions (Kumar et al. 2011). In this study, the significant increase of RBCs count, $\mathrm{Hb}$ concentration and $\mathrm{Ht}$ value was observed in all experimental groups except the group exposed to $\mathrm{Ca}(\mathrm{OCl})_{2}$ plus GAC. This may be related to the hypoxia due to gills dysfunction and/or dehydration status besides fish response to the stressful conditions (Zeitoun 1977; Smith 2019). Alterations in the hemoglobin concentration under any type of exposure to chemicals or poisonous stressors are indicator to the oxygen utilization and metabolism, as oxygen transport in the blood depends upon the hemoglobin content of RBCs in the blood of fish; therefore, $\mathrm{Hb}$ concentration and $\mathrm{RBCs}$ count are considered as reflectors of the pollution stress. Physiological responses of fish to different stressors include of primary, secondary and tertiary responses in accordance with the stage and degree of stress (Ahmed et al. 2020), so insignificant increase of the mentioned hematological parameters in the group exposed to $\mathrm{Ca}(\mathrm{OCl})_{2}$ plus GAC may reveal that the combined exposure of fish to both of agents may induce negative impacts on the hematopoietic system and start to lower the different hematological parameters.

According to the results of leukogram, leukocytosis occurred as a consequence of the significant increase of heterophils, lymphocytes and monocytes counts in all experimental groups except the group exposed to
$\mathrm{Ca}(\mathrm{OCl})_{2}$ plus $\mathrm{GAC}$, which showed insignificant increase in the monocytes count in comparison to the control group, these changes may have occurred as inflammatory response from heterophils and monocytes to antigenic stimulation. Also, lymphocytosis is a suggestive of immunogenic stimulation in body (Thrall et al. 2012) These results are similar to that previously reported by Sakthika and Felicitta (2017) and Comfort et al. (2019), where it was observed that leukocytosis after exposure of fish to chlorine as well as lymphocytosis, where chlorine enhanced release of lymphocytes from lymphoid tissues to deal with the toxic condition.

Fish liver is considered a good model for the interaction between the environmental factors and hepatic structure and functions. Where many environmental stressors have an effect on fish liver and induce metabolic disturbances and structural damage (Datta-Munshi and Dutta 1996). In this study, there was a marked elevation in the serum ALT and AST activities in all experimental groups. These results may relate to hepatocellular damage or cellular injury and leakage of transaminases into the circulation (Rudneva 2014). On the other side, serum ALP activity showed marked reduction in all experimental groups, and this could be attributed to the damage or disturbance in cell organelles such as, cell membrane transport system and endoplasmic reticulum where ALP is responsible for membrane transport (Al-Ghanim et al. 2020). Also, the exposure of fish to chemicals can inhibit the activity or synthesis of ALP enzyme (Goetz 1980), so the decrease in ALP activity may be considered as an index of damage liver parenchyma and hepatocellular necrosis (Onikienko 1963). According to the results of serum bilirubin, a significant increment in (total, direct and indirect) bilirubin level was observed in all tested groups and this may be due to the hepatic parenchyma injury which resulted from xenobiotic exposure and lowering the hepatic ability to conjugate and excrete the bilirubin leading to a build-up of indirect and direct bilirubin in the blood (Luu 2013).Various observed histopathological lesions in the liver in the different experimental groups in this study confirmed the results of the measured biochemical tests.

Proteins are a major component in the blood and needed to build and repair tissues and raise an immune response in the body. As represented in this study, serum total proteins concentration showed significant increase in all experimental groups and this change may relate to globulins concentration, which was comparatively high in the different groups and this may reflect the high immunological defense response due to chemical exposure challenges (Javed et al. 2017). Regarding the results of serum albumin in the group exposed to $\mathrm{Ca}(\mathrm{OCl})_{2}$ alone and according to the result of previous study of Zeitoun (1977), the marked increase in this parameter may be due to the hemoconcentration.

In fish, the functions of excretion and osmoregulation are closely related and performed by both of gills and kidneys (Smith 2019). Generally, the fish produce a small amount of creatine, uric acid and creatinine (Thrall et al. 2012). Creatine kinase activity in the liver produce creatine phosphate, which is broken down in the muscles to convert ADP into ATP, creatinine is a product of creatine phosphate breakdown, which is finally excreted 
by the kidneys (Stoskopf 1993). The significant decrease in the level of serum creatinine in all experimental groups in this study may be due to lowering the activity of creatine kinase in the dysfunctional liver, which leads to decrease creatine phosphate concentration and this in turn leads to decrease the creatinine concentration in the blood. Also, the reduction in the basal metabolism may consequently reduce ATP and creatinine production (Mirghaed et al. 2018).

Blood concentrations of electrolytes such as $\mathrm{Na}^{+}$and $\mathrm{Cl}^{-}$are indicative of a fish's ability to osmoregulate (McDonald and Milligan 1992). Significant increase of serum sodium and chloride ions levels in all fish groups in comparison with control one may be attributed in general to kidney dysfunction and gills injury, which in turn affects the osmoregulatory ability (Gabriel et al. 2019). According to previous studies on animals, the exposure to hypochlorite can result in hypernatremia and hyperchloremia with metabolic acidosis (Plumlee 2003). According to some previous studies in animals, the activated carbon can induce the increase in sodium concentration in blood (Drobatz et al. 2019).

Regarding the results of serum calcium and phosphorus in this study, hypercalcemia and hyperphosphatemia, which observed in all experimental groups, may be due to the impairment of renal function and poor calcium excretion alongside with phosphorus (Randels-Thorp and Liss 2017). Also, according to a study of Groff and Zinkl (1999) on Cyprinids (freshwater fish), hypoxia leads to reduction of glomular filtration rate which leads to hypercalcemia and hyperphosphatemia. Also, increasing of serum phosphate concentration might be because of different tissues damage that causing the phosphorous molecules release and the consequent elevation of its level (DiBartola and Willard 2011).

Ammonia is a prime end product of amino acid metabolism in the fish and most of fish excrete it as a main nitrogenous waste product. According to the results of this study, a marked increase in serum ammonia concentration in all experimental groups may be due to the swelling and inflammation that happened combined with gills damage which leading to increase diffusion distance between blood and water and lack of passive diffusion of ammonia to water (Thrall et al. 2012), where ammonia excrete mainly by the gills in fish (Evans et al. 2014). Numerous observed histopathological lesions in the kidneys and gills in the different experimental groups in this study confirmed the results of the measured biomarkers (serum $\mathrm{Na}, \mathrm{Cl}, \mathrm{Ca}, \mathrm{P}$ and ammonia).

Measurement of antioxidants and oxidative stress markers could be used as a diagnostic tool for fish exposure to pollutants or deleterious chemicals (Acton 2013). MDA is a major degradation product of lipid hydroxides (LPO) and is often used as an effective biomarker for evaluating LPO when aquatic species are exposed to pollutants xenobiotics (Huang et al. 2020). According to the results of this study, MDA levels in the liver, kidneys and gills were significantly elevated in all experimental fish groups. Such increase in the level of MDA in different tissues reflects the excessive ROS production and the severity of free radical attack on body tissues (Dong et al. 2018). In another context, significant increase of $\mathrm{H}_{2} \mathrm{O}_{2}$ level in different tested tissues (liver, kidneys and gills) in all experimental groups may indicate increasing level of oxidative stress in these tissues, which triggers different deleterious biochemical reactions that will participate in lowering cellular function (Farooqui and Farooqui 2012; Biller and Takahashi 2018). In the normal health condition, antioxidant defense system of any organism, can remove ROS and protect the variety numbers of biological molecules from ROS attack. However, when ROS production under the influence of xenobiotics exceeds the scavenging capability of antioxidant defense system in the body, the protection system imbalance will be occurred, and consequently weakening the activity of antioxidant enzymes (Huang et al. 2020). As shown, in the present study the activity of SOD was significantly decreased in the liver, kidneys and gills in all experimental groups may be attributed to the excessive superoxide ions production in the fish tissues which exceeds the capacity of SOD to remove or neutralize it (Zahran et al. 2018).

Regarding the results of the most measured parameters, the pronounced changes were observed in the group exposed to both of $\mathrm{Ca}(\mathrm{OCl})_{2}$ and $\mathrm{GAC}$ followed by group exposed to GAC alone and finally the group exposed to $\mathrm{Ca}(\mathrm{OCl})_{2}$ alone. So that, these results shed light on the possible adverse effects of activated carbon on aquatic creatures biological system and therefore that the combined negative impacts of both $\mathrm{Ca}(\mathrm{OCl})_{2}$ and $\mathrm{GAC}$ produced marked changes in all biological parameters in this group in comparison with the other groups especially the group exposed to GAC alone revealed significant changes. Few previous studies recorded that some negative impacts of activated carbon on aquatic invertebrates and certain benthic organisms in sediment which may confirm the results of this study. Jonker et al. (2009) found that addition unwashed activated carbon to sediments can be toxic to some aquatic invertebrates (Lumbriculus variegatus, Daphnia magna, and Corophium volutator) based on different mechanisms of toxicity including of physical or chemical stress on organisms. Also, some negative effects for AC were tested in the different forms and ways and have been reported by some studies and represented in the inhibition of the growth, reduction of the weight, decreased body lipid content and the behavior disturbance (such as feeding behavior) in different aquatic invertebrates (Nybom et al. 2012; Janssen and Beckingham 2013; Abel et al. 2017). According to the results of the study of Kupryianchyk (2011), addition of AC to clean and unpolluted sediment, caused $100 \%$ mortality of Gammarus pulex (benthic specie), whereas AC did not cause complete mortality in $G$. pulex when used in polluted sediment. So can say that AC may be effective and useful in reducing toxic substances in certain environment, but also may be the cause of different adverse effects on the lived creatures in this environment.

\section{Conclusion}

Under the light of this study, it can be concluded that the presence of $\mathrm{Ca}(\mathrm{OCl})_{2}$ in Clarias gariepinus aquatic environment caused negative impacts on the fish biological markers which appeared in the form of hematological disturbances, hepato-renal impairment and oxidative stress in the different organs as well as 
histopathological alterations in the tested organs, which provide both supplementary and supportive information on potential target organs toxicity of chlorine. On the other hand, in spite of importance of GAC for chlorine removal and reduction of pollutants exposure for aquatic organisms in general, this study found several adverse results after using activated carbon on the different tested parameters in fish under the condition of this experiment. Finally, it can be said that these results are very important in assessing the seriousness and toxicity of chlorine and its compounds and also important for the references of future studies. Also, the proper precautions need to be taken for efficient and safe use of $\mathrm{AC}$ in the aquatic environment as well as the there is need for the additional investigations on possible secondary effects of improper use of it.

\section{Acknowledgment}

The author would appreciate and thank Prof. Dr. AlSayed Al-Attar, Professor of Pathology, Faculty of Veterinary Medicine, Zagazig University, Egypt, for his worthy help in histopathological slides reading and examination.

\section{REFERENCES}

Abel S, Nybom I, Mäenpää K, Hale SE, Cornelissen G and Akkanen J, 2017. Mixing and capping techniqu0es for activated carbon based sediment remediation efficiency and adverse effects for Lumbriculus variegatus. Water Research 114: 104-112. https://doi.org/10.1016/j.watres.2017.02.025

Acton QA, 2013. Issues in Veterinary Research and Medicine: 2013 Edition, Scholarly editions, Atlanta, Georgia, USA.

Ahmed I, Reshi QM and Fazio F, 2020. The influence of the endogenous and exogenous factors on hematological parameters in different fish species: a review. Aquaculture International 28: 869-899. https://doi. org/10.1007/s10499019-00501-3

Al-Ghanim KA, Mahboob S, Vijayaraghavan P, Al-Misned FA, Kim YO and Kim H, 2020. Sub-lethal effect of synthetic pyrethroid pesticide on metabolic enzymes and protein profile of non-target Zebra fish, Danio rerio. Saudi Journal of Biological Sciences 27: 441-447. https://doi.org/ 10.10 16/j.sjbs.2019.11.005

Aly HA, Abdel Rahim MM, Lotfy AM, Abdelaty BS and Sallam GR, 2016. The applicability of activated carbon, natural zeolites, and probiotics $(\mathrm{EM} \AA)$ and its effects on ammonia removal efficiency and fry performance of European seabass Dicentrarchus labrax. Journal of Aquaculture Research and Development 7: 11. https://doi.org/10. $\underline{\text { 4172/2155-9546.1000459 }}$

Aswale M, Ghongade R, Arora MS and Sinha S, 2019. Acute toxicity assessment on biochemical and histopathological alterations of bleaching powder-exposed fresh water fish Labeo rohita. International Journal of Fisheries and Aquatic Studies 7: 562-568.

Batley GE and Simpson SL, 2020. Short-term guideline values for chlorine in marine waters. Environmental Toxicology and Chemistry 39: 754-764. https://doi.org/10.1002/ etc. 4661

Batley GE, Adams MS and Simpson SL, 2021. Short-Term Guideline Values for Chlorine in Freshwaters. Environmental Toxicology and Chemistry 40: 1341-1352. https://doi.org 10.1002/etc.4984

Biller JD and Takahashi LS, 2018. Oxidative stress and fish immune system: phagocytosis and leukocyte respiratory burst activity. Anais da Academia Brasileira de Ciências
90:3403-3414. https://doi. org/ 10.15 90/0001-3765201820 $\underline{170730}$

Burtis CA and Ashwood ER, 1999. Tietz Textbook of Clinical Chemistry, 3rd Ed. W. B. Saunders Co., Philadelphia.

Campbell T W, 2015. Hematology, an Issue of Veterinary Clinics of North America: Exotic Animal Practice, Vol 18 Elsevier, Philadelphia, USA

Collivignarelli C, Sorlini S and Belluati M, 2006. Chlorite removal with GAC. American Water Works Association 98: 74-81. https://doi.org/10.1002/j.1551-8833.2006.tb $07825 . x$

Comfort A I, Tobiloba I and Oyeleye OJ, 2019. Haematological assessment and piscicidal effect of sodium hypochlorite on juvenile Heterobranchus bidorsalis (Geoffroy st. hiliare, 1809). International Journal of Fisheries and Aquaculture Research 5: 1-9.

Cooke SJ and Schreer JF, 2001. Additive effects of chlorinated biocides and water temperature on fish in thermal effluents with emphasis on the great lakes. Reviews in Fisheries Science 9: 69-113. https://doi.org/10.1080/20016491101 717

Datta-Munshi JS and Dutta HM, 1996. Fish Morphology, 1st Ed. CRC Press, Boca Raton, Florida, USA.

DiBartola SP and Willard MD, 2011. Disorders of Phosphorus: Hypophosphatemia and Hyperphosphatemia. In: DiBartola S P (ed), Fluid, Electrolyte, and Acid-base Disorders in Small Animal Practice. Elsevier Saunders, Saint Louis, MO. https://doi.org/10.1016/B978-1-4377-0654-3.00014-7

Dong WQ, Sun HJ, Zhang Y, Lin H J, Chen JR and Hong HC, 2018. Impact on growth, oxidative stress, and apoptosisrelated gene transcription of zebrafish after exposure to low concentration of arsenite. Chemosphere 211: 648-652. https://doi.org/10.1016/i.chemospher e.2018.08.010

Drobatz K J, Hopper K, Rozanski E and Silverstein DC, 2019. Textbook of Small Animal Emergency Medicine, I\&II. John Wiley and Sons, Inc, USA. https://doi.org/10. 1002/ 9781119028994

El-Sherbiny MA, EL-Chaghaby GA and Abd El-Shafea YM, 2019. Treatment of aquaculture waste effluent to be reused in fish culture in Egypt. Egyptian Journal of Aquatic Biology and Fisheries 23: 233 -243. https://doi.org/10. 21608/ejabf.2019.27272

Evans DH, Claiborne JB and Currie S, 2014. The Physiology of Fishes, 4th Ed. CRC press (Taylor \& Francis Group), Boca Raton (Florida), USA.

Farooqui A and Farooqui AA, 2012. Oxidative Stress in Vertebrates and Invertebrates: Molecular Aspects of Cell Signaling. Wiley-Blackwell, USA. https://doi.org /10.1002/ 9781118148143

Fisher DJ, Burton DT, Yonkos LT, Turley SD, Ziegler GP and Turley BS, 2003. Derivation of acute ecological risk criteria for chlorite in freshwater ecosystems. Water Research 37: 4359-4368. https://doi.org/10.1016/S0043-1354(03)00433$\underline{0}$

Gabriel UU, Edori OS and Egobueze EC, 2019. Plasma enzymes and electrolytes in Heterobranchus bidorsalis treated with cypermethrin. Biochemistry and Analytical Biochemistry 8 : 380.

Ganesh R, Leong LYS, Tikkanen MW and Peterka GJ, 2006. Dechlorination. In: Wang L K, Hung YT and Shammas NK (eds), Advanced Physicochemical Treatment Processes. Handbook of Environmental Engineering, Vol 4, Humana Press. https://doi.org/10. 10 07/978-1-59745-029-4_13

Ghernaout D, 2017. Water treatment chlorination: An updated mechanistic insight review. Chemistry Research Journal 2 : 125-138.

Goetz W, 1980. Diagnostik Von Lebererkran- Kungen (In German). G.1.T. Verlag Ernst Giebeler, Darmstedt. Germany. 
Groff J M and Zinkl J G, 1999. Hematology and clinical chemistry of cyprinid fish. Common carp and goldfish. Veterinary Clinics of North America: Exotic Animal Practice 2: 741-746. https://doi.org/10.1016/S10949194(17)30120-2

Halder M, Kienzler A, Whelan M and Worth A, 2014. EURL ECVAM Strategy to replace, reduce and refine the use of fish in aquatic toxicity and bioaccumulation testing. Publications Office of the European Union. https://doi: $\underline{10.2788 / 084219}$

Halliwell B and Gutteridge JMC, 1989. Free Radicals in Biology and Medicine, 2nd Ed. Clarendon Press, Oxford.

Hamdullah, Khan MZ, Khan A and Javed I, 2010. Toxicopathological effects of sodium hypochlorite administration through drinking water in female Japanese quail (Coturnix japonica). Human and Experimental Toxicology 29: 779788. https://doi.org/10.1177/0960327110361755

Harvey JW, 2012. Veterinary Hematology: A Diagnostic Guide and Color Atlas. St. Louis Mo., Elsevier Saunders, USA.

Hatt JW, Germain E and Judd SJ, 2013. Granular activated carbon for removal of organic matter and turbidity from secondary wastewater. Water Science and Technology 67: 846-853. https://doi.org/10. 21 66/wst.2012.644

Heath AG, 1997.Toxicity of intermittent chlorination to fresh water fish: Influence of temperature and chlorine form. Hydrobiologia 56: 39-47. https://doi. org/10.1007/B F 0023284

Hemdal JF, 2010. HLLE and activated carbon: Looking for a link. Coral Magazine 7: 12-14.

Hemdal JF and Odum RA, 2011. The role of activated lignite carbon in the development of head and lateral line erosion in the ocean surgeonfish. North American Journal of Aquaculture 73: 489-492. https:// doi. org /10.1080/152220 55.2011 .635781

Henry RJ, 1974. Clinical Chemistry, 2nd Ed. Harper and Row publisher, New York, USA.

Huang X, Li Y, Wang T, Liu H, Shi J and Zhang X, 2020. Evaluation of the oxidative stress status in Zebrafish (Danio rerio) liver induced by three typical organic UV Filters (BP-4, PABA and PBSA). International Journal of Environmental Research and Public Health 17: 651. https://doi.org/10.3390/ijerph17020651

Ibrahem MD, 2012. Experimental exposure of African catfish Clarias gariepinus (Burchell, 1822) to phenol: Clinical evaluation, tissue alterations and residue assessment. Journal of Advanced Research 3: 177-183. https://doi.org/ 10.1016/j.jare. 2011.07.002

IPCS, 2000. Environmental Health Criteria 216. Disinfectants and Disinfectant By-Products. International Programme on Chemical Safety. https://www.who.int/ipcs/publications/ ehc/216 disinfectants part 1.pdf

Janssen EML and Beckingham BA, 2013. Biological responses to activated carbon amendments in sediment remediation. Environmental Science \& Technology 47: 7595-7607. https://doi.org/10.1021/es401_142e

Javahery S, Nekoubin H and Moradlu AH, 2012. Effect of anesthesia with clove oil in fish (review). Fish Physiology and Biochemistry 38: 1545-1552. https://doi.org/10.1007/ s106 95-012-9682-5

Javed M, Ahmad MDI, Usmani N and Ahmad M, 2017. Multiple biomarker responses (serum biochemistry, oxidative stress, genotoxicity and histopathology) in Channa punctatus exposed to heavy metal loaded waste water. Scientific Reports 7: 1675. https://doi.org/10.1038/s 41598-017-01749-6

Jonker MTO, Suijkerbuijk MPW, Schmitt H and Sinnige TI, 2009. Ecotoxicological effects of activated carbon addition to sediments. Environmental Science \& Technology 43: $5959-5966$.
Khan A, Ullah M and Khan MZ, 2008. Pathological effects of sodium hypochlorite administration through drinking water in male Japanese quails (Coturnix japonica). Human and Experimental Toxicology 27: 773-780. https://doi.org/ $10.1177 / 0960327108097435$.

Kolawole AS and Olukunle O, 2014. Toxicity of calcium hypochlorite on fingerlings of Clarias gariepinus (burchell, 1822). Ibadan Journal of Agricultural Research 10: 108127.

Kowalska B, Kowalski D and Musz A, 2006. Chlorine decay and disinfection by-products in water distribution systems. Environment Protection Engineering 32: 5-16.

Kumar N, Prabhu PAJ, Pal A, Remya S, Aklakur M, Rana R, Gupta S, Raman R and Jadhao S, 2011. Anti-oxidative and immuno-hematological status of Tilapia (Oreochromis mossambicus) during acute toxicity test of endosulfan. Pesticide Biochemistry and Physiology 99: 45-52. https://doi.org/10.1016/j.pestbp.2010.10.003

Kupryianchyk D, Reichman EP, Rakowska MI, Peeters ETHM, Grotenhuis JTC and Koelmans AA, 2011. Ecotoxicological effects of activated carbon amendments on macroinvertebrates in nonpolluted and polluted sediments Environmental Science \& Technology 45: 8567-8574. https://doi.org /10.1021/es2014538

Luu TT, 2013. Investigation into jaundice in farmed catfish (Pangasianodon hypophthalmus, Sauvage) in the Mekong Delta, Vietnam. Ph.D. Thesis. University of Stirling.

Mahjoor AA and Loh R, 2008. Some histopathological aspects of chlorine toxicity in rainbow trout (Oncorhynchus mykiss). Asian Journal of Animal and Veterinary Advances 3: 303-306. https://doi.org/10.3923/ajava.2008.303.306

Menéndez-Díaz JA and Martín-Gullónb I, 2006. Types of carbon adsorbents and their production. Activated carbon surfaces in environmental remediation (Interface science and technology series, 7) T. Bandosz Ed. Elsevier, 1-48. https://doi.org/10.1016/S1573-4285(06)80010-4

McDonald DG and Milligan CL, 1992. Chemical Properties of the Blood. In: Hoar W S, Randall DJ and Farrell AP (eds), Fish Physiology, Vol 12, Part B: The Cardiovascular System, Academic Press, San Diego.

Millward RN, Bridges TS, Ghosh U, Zimmerman JR and Luthy $\mathrm{RG}, 2005$. Addition of activated carbon to sediments to reduce PCB bioaccumulation by a polychaete (Neanthes arenaceodentata) and an amphipod (Leptocheirus plumulosus). Environmental Science \& Technology 39: 2880-2887. https://doi.org/10.1021/es048768x

Mirghaed AT, Ghelichpour M, Mirzargar SS, Joshaghani H and Mousavi HE,2018. Toxic effects of indoxacarb on gill and kidney histopathology and biochemical indicators in common carp (Cyprinus carpio). Aquaculture Research 49 : 1616-1627. https://doi.org/10.1111/are.13617

Neely WE and Phillipson J, 1988. Clinical Chemistry 34: 1868. https://doi.org/10.1093/clinchem/34.9.1866

Nishikimi M, Appaji N and Yagi K, 1972. The occurrence of superoxide anion in the reaction of reduced phenazine methosulfate and molecular oxygen. Biochemical and Biophysical Research Communications 46: 849-854. https://doi.org/10.1016/S0006-291X(72)80218-3

Noga EJ, 2010. Fish Disease: Diagnosis and Treatment, $2^{\text {nd }} E d$ Wiley-Blackwell, Iowa, USA. https://doi.org/10.1002/978 1118786758

NRC, 2011. Nutrient Requirements of Fish and Shrimp. National Academies Press, Washington, DC.

Nybom I, Werner D, Leppänen MT, Siavalas G, Christanis K, Karapanagioti HK and Akkanen J, 2012. Responses of Lumbriculus variegatus to activated carbon amendments in uncontaminated sediments. Environmental Science \& Technology 46: 12895-12903. https://doi.org/10.1021/ es303430j 
Ohkawa H, Ohishi Í and Yagi Ê, 1979. Assay for lipid peroxides in animal tissues by thiobarbituric acid reaction. Analytical Biochemistry 95: 351-358. https://doi.org/10.101 6/00032697(79)90738-3

Onikienko FA, 1963. Enzymatic changes from early stages of intoxication with small doses of chloroorganic insecticides. Giginea. I. Fiziol. Ruda. Pro. Toksilol. Klinika (Kietcv: Gos IZ. Med. Lit. UKHS), pp: 77.

Parker R, 2002. Aquaculture Science, 2nd Ed. Chapter 10: Water Requirements for Aquaculture, USA.

Plumlee K, 2003. Clinical Veterinary Toxicology. 1st Ed. Mosby, St. Louis, MO.

Pons A and Boyd C, 1998. Chlorination of channel catfish ponds. Journal of the World Aquaculture Society 29: 432440. https://doi.org/10.1111/j.1749-7345.1998.tb00667.x

Randels-Thorp A and Liss D, 2017. Acid-Base and Electrolyte Handbook for Veterinary Technicians. Wiley-Blackwell, Iowa, USA. https://doi.org/10.1002/9781118922859

Roberts H and Palmeiro BS, 2008.Toxicology of aquarium fish. Veterinary Clinics: Exotic Animal Practice 11: 359-374. https://doi.org/10.1016/j.cvex.2007.12.005

Rudneva I, 2014. Biomarkers for Stress in Fish Embryos and Larvae. CRC Press, Boca Raton, Florida, USA. https://doi.org/10.1201/b15378

Sakthika T and Felicitta J, 2017. Toxic effect of chlorine on selected blood parameters of the fish Mystus montanus. International Journal of Science, Engineering and Management 2: 163-166.

Salama RS, Kiwaan H and Mostafa MR, 2016. Remediating free chlorine from aqueous solution using hydrous zirconium oxide impregnated carbons. Journal of Chemical Engineering \& Process Technology 7: 3 .

Schmittinger P, 2000. Chlorine: Principles and Industrial Practice, $1^{\text {st }}$ Ed. Wiley-Vch, Germany. https://doi.org/ $\underline{10.1002 / 9783527613380}$
Smith SA, 2019. Fish Diseases and Medicine. CRC Press (Taylor and Francis Group), Boca Raton, Florida, USA.

Snedecor GW and Cochran WG, 1994. Statistical Method, 8th Ed. Iowa State University Press, Ames, Iowa.

Stoskopf MK, 1993. Fish Medicine. WB Saunders Company, St. Louis, MO.

Suvarna KS, Layton C and Bancroft JD, 2013. Bancroft's Theory and Practice of Histological Techniques, 7th Ed. Churchill Livingstone Elsevier, China.

Svobodová Z, Lloyd R, Machova J and Vykusova B, 1993. Water Quality and Fish Health. FAO Fisheries Department. Rome, Italy.

Thrall MA, Weiser G, Allison R and Campbell TW, 2012. Veterinary Hematology and Clinical Chemistry, 2nd Ed. Wiley-Blackwell, Ames, IA, USA.

Wu SL, Wei W and Ni BJ, 2021. Enhanced methane production from anaerobic digestion of waste activated sludge through preliminary pretreatment using calcium hypochlorite. Journal of Environmental Management 295: Article \# 113346. https://doi.org/10.1016/j.jenvman.2021.113346

Yonkos LT, Fisher DJ, Wright DA and Kane AS, 2000. Pathology of fathead minnows (Pimephales promelas) exposed to chlorine dioxide and chlorite. Marine Environmental Research 50: 267-271. https://doi.org/ 10.1016/S0141-1136 (00)00048-9

Zahran E, Risha E, Awadin W and Palićd D, 2018. Acute exposure to chlorpyrifos induces reversible changes in health parameters of Nile tilapia (Oreochromis niloticus). Aquatic Toxicology 197: 47-59. https://doi.org/10.1016/ j.aquatox.2018.02.001

Zeitoun IH, 1977. The effect of chlorine toxicity on certain blood parameters of adult rainbow trout (Salmo gairdneri). Environmental Biology of Fishes 1: 189-195. https://doi.org/10.1007/BF00000410 